\title{
Studying Computer Science in a Multidisciplinary Degree Programme: Freshman Students' Orientation, Knowledge, and Background
}

\author{
Karlheinz Kautz and Uffe Kofoed \\ Copenhagen Business School, Frederiksberg, Denmark
}

\author{
Karl.Kautz@cbs.dk ugk.inf@cbs.dk
}

\section{Executive Summary}

Teachers at universities are facing an increasing disparity in students' prior IT knowledge and, at the same time, experience a growing disengagement of the students with regard to involvement in study activities. As computer science teachers in a joint programme in computer science and business administration, we made a number of similar observations. We also noted increasing difficulties with mathematics and see a growing number of students with previous knowledge in computer science, while others have little or no expertise in this area. These observations cause problems and present a major challenge for teachers. To get a better understanding and as a prerequisite for reforming the programme we posed four research questions: What are the students' motives and expectations with regard to the chosen study programme? To what extent are the students engaged in non-academic work activities? What prior knowledge do the students have about IT and computer science? What off campus access do the students have to IT facilities?

Our findings provide a number of interesting indications. The results regarding motives and expectations suggest that there ought to be a good basis for the students to improve their efforts in computer science. However, as the majority does not know what kind of work to carry out in the future, better information about the programme and relevant jobs should be provided. Concerning the students' disengagement and its possible relation to their external workload, no conclusions can be drawn and this issue has to be researched further. The same is true about the students' expertise in mathematics. The students' previous knowledge seems to be so comprehensive that it should be considered in the teaching and inform the whole curriculum design. As there are still a substantial number of students who arrive at the programme with no previous knowledge, it is however necessary to design a syllabus and organise the course programme to accommodate different types of students. The survey also shows that IT is a natural toolset for the students, which in the future should be used more deliberately for the education.

The paper provides the opportunity for other faculty to reflect on the role their students' backgrounds and expectations may play in the classroom experience. A copy of the survey is included

Material published as part of this journal, either on-line or in print, is copyrighted by the publisher of the Journal of Information Technology Education. Permission to make digital or paper copy of part or all of these works for personal or classroom use is granted without fee provided that the copies are not made or distributed for profit or commercial advantage AND that copies 1) bear this notice in full and 2) give the full citation on the first page. It is permissible to abstract these works so long as credit is given. To copy in all other cases or to republish or to post on a server or to redistribute to lists requires specific permission and payment of a fee. Contact Editor@JITE.org to request redistribution permission. in the appendix as a guide for those interested in conducting a similar study of their own student population.

Keywords: IT education, prior computer science knowledge, student disengagement, mathematics problems, access to IT facilities, students' external workload. 


\section{Introduction}

Teachers and lecturers at universities are facing an increasing disparity in students' prior IT knowledge, skills and abilities (Meredyth, Russel, Blackwood, Thomas, \& Wise, 1999) and at the same time experience a growing disengagement of the students with regard to active involvement in study activities (McInnis, James, \& Hartley, 2000; McInnis, James, \& McNaught, 1995).

The authors of these reports discuss these issues on a broad level with no regard to any specific degree programme. As computer science and information system development teachers in a joint bachelor and master programme in computer science and business administration, during the last three years we made a number of similar observations, first of all the students' decreasing efforts in computer science subjects both in terms of preparation and active participation in lectures and exercises. We also noted increasing difficulties with mathematics related topics. Simultaneously we are seeing a growing number of students with previous knowledge in computer science, while others have little or no expertise in this area. These observations cause problems and present a major challenge for teachers in their daily educational practice. Questions arise which ask, if students are arriving at university with pre-existing skills and knowledge and a decreasing engagement in study work, what impact does this have on the everyday business of teaching and how can these changed conditions been taken into account when (re-)designing teaching programmes?

A review of literature related to IT and computer science education showed that beyond the continuous curriculum debate (e.g. Denning, 1992; Denning, Comer, Gries, Mulder, Tucker, Turner \& Young, 1989; Kautz, 1996; Samaka, 2002) and especially the significant role of mathematics in this context (Beaubouef, 2002; Dijkstra, 1989; Gries, 1991), little attention is paid to these matters by IT education scholars. Thus, to get a better understanding and as a prerequisite for developing countermeasures and for reforming both course contents, structure and pedagogical approaches we investigated disengagement and the disparity in prior IT knowledge of computer science and IT students by posing four research questions:

1. What are the students' motives and expectations with regard to the chosen study programme?

2. To what extent are the students engaged in non-academic work activities?

3. What prior knowledge do the students have about IT and computer science?

4. What off campus access do the students have to IT facilities?

We believe that beyond ourselves the answers to these questions might give others in comparable settings a basis for reflection and action. The results may be used to inform future curriculum design, including teaching and learning strategies in computer science programmes.

The remainder of the article is organised as follows. In the next section we introduce the Computer Science and Business Administration Bachelor and Master degree programme which builds the background for our research and then describe our research approach. Thereafter we present and discuss our research results and finish the article with some conclusions and summarize questions for possible future research.

\section{Research Background}

Our research is based on a single case study. Knowledge gained through case studies might not be formally generalizable, but this does not mean that it does not contribute to the collective body of knowledge of a discipline (Flyvberg, 1992) and can therefore be informative and useful. To give the readers the necessary context for their own assessments as to whether our findings are applicable to their situation we describe the sample case organisation in more detail here. 
The research took place at the Copenhagen Business School, an independent business university in Denmark. Since 1984 it offers a fulltime combined degree programme in Computer Science and Business Administration on both a bachelor and a master level. On the bachelor level the programme consists of a three-year curriculum, in which all courses are obligatory. The programme's subjects and course modules together with the expected hours of effort put in by the students are depicted in Table 1.

The subsequent master programme has a duration of two years and has only one compulsory course in theory of science and the remainder are to a third electives from computer science/informatics and a third organisational science/economy classes with a last third of freely selectable classes on these subjects.

Table 1: Subjects and modules of the Computer Science and Business Administration Bachelor Programme at Copenhagen Business School, Denmark

\begin{tabular}{|c|c|c|c|c|c|}
\hline \multicolumn{2}{|c|}{ 1. year } & \multicolumn{2}{|c|}{ 2. year } & \multicolumn{2}{|c|}{ 3. year } \\
\hline 1. term & 2. term & 3. term & 4. term & 5. term & 6. term \\
\hline \multicolumn{2}{|c|}{$\begin{array}{l}\text { Computer Science and } \\
\text { Information Systems } \\
\text { Programming } \\
\text { Programme development } \\
\text { Databases }\end{array}$} & \multicolumn{2}{|c|}{\begin{tabular}{|l} 
Computer Science and \\
Information Systems \\
Machine architecture \\
Distributed systems \\
Operation systems \\
Network technology and \\
infrastructure \\
Systems development
\end{tabular}} & \multicolumn{2}{|l|}{ 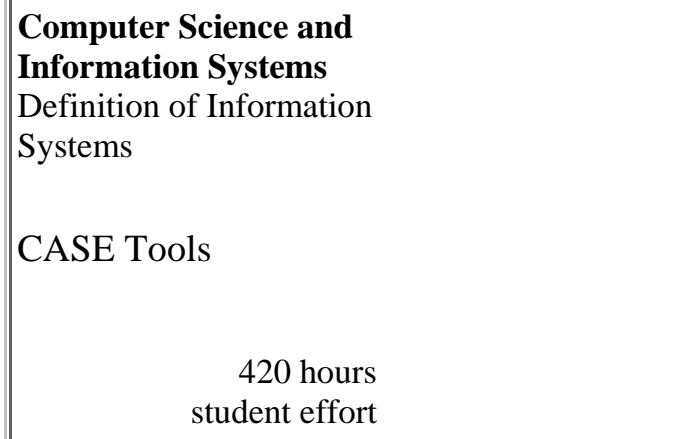 } \\
\hline \multicolumn{2}{|c|}{$\begin{array}{l}\text { Organisational Science } \\
\text { Decision theories, } \\
\text { Organisational culture } \\
\text { Group sociology } \\
\text { General management } \\
\text { Research methods }\end{array}$} & \multicolumn{2}{|c|}{$\begin{array}{l}\text { IT Philosophy } \\
\text { IT Management } \\
\text { IT innovation } \\
\text { IT project management }\end{array}$} & \multirow{2}{*}{\multicolumn{2}{|c|}{\begin{tabular}{|l} 
IT Management \\
IT strategy \\
IT change management \\
210 hours \\
student effort
\end{tabular}}} \\
\hline & \begin{tabular}{r||}
336 hours \\
student effort
\end{tabular} & & \begin{tabular}{r|}
336 hours \\
student effort
\end{tabular} & & \\
\hline \multicolumn{2}{|c|}{$\begin{array}{l}\text { Economy } \\
\text { Macro economics } \\
\text { Micro economics }\end{array}$} & \multicolumn{2}{|l|}{$\begin{array}{l}\text { Economy } \\
\text { Accounting } \\
\text { Marketing }\end{array}$} & \multicolumn{2}{|r|}{ Final Project } \\
\hline & \begin{tabular}{r||}
504 hours \\
student effort
\end{tabular} & & \begin{tabular}{r||}
672 hours \\
student effort
\end{tabular} & & $\begin{array}{r}840 \text { hours } \\
\text { student effort }\end{array}$ \\
\hline \multicolumn{2}{|c|}{$\begin{array}{l}\text { Social Science } \\
\text { Business and Society }\end{array}$} & & & \multicolumn{2}{|r|}{ IT Law } \\
\hline & \begin{tabular}{r||}
168 hours \\
student effort
\end{tabular} & & & & $\begin{array}{r}210 \text { hours } \\
\text { student effort }\end{array}$ \\
\hline
\end{tabular}

The students of the programme are to 95\% young Danes, the other 5\% are largely from the other Scandinavian countries; rarely someone from outside Denmark chooses the programme, not least because most of the courses are taught in Danish. The students are 90\% males and 10\% females; 
usually $80 \%$ of the bachelor students continue on the master level, which as prerequisite requires a bachelor degree comparable to the one provided by the programme itself.

Due to government regulations $75 \%$ of the students admitted to the bachelor programme have to come directly from a three year long general or vocational upper secondary education, which after nine years of primary education provides the schooling necessary for a university study. The remaining 25\% achieve admittance to the programme either after having tried or finished another higher education or after social or military service which is taken into account when the time passed since their upper secondary education graduation and their graduation mark are correlated for admittance. The first group of students is typically between 18 - 20 years old at the start of the programme, the second between 24 - 26 years.

The Danish school system requires students to specialize with different levels of expertise in various subjects. Level A is considered the highest level of specialisation, level B the medium level and level C the lowest level. To be able to enter the Computer Science and Business Administration programme, students have to at least chosen mathematics on level B. Within the levels 10 different marks are given, with 13 being the best.

During the last three years between 140 and 180 students out of 360 - 480 applicants have been admitted to the programme. For admittance, a central government agency assigns students to the study programme they have applied for, based on the number of available places - also determined by government -, on special requirements like the mathematics level, and the average mark achieved by the students through their upper secondary education.

While the cut off overall average mark for the last applicants on the applicant list to be admitted to the Computer Science and Business Administration programme was typically between 8 and 9 during the last ten years, at the time of the study in 2002 it had dropped to 7,6.

In total in 2002 the programme had 450 active bachelor and 250 master students.

Beyond the students' efforts outside organised classes teaching and learning in the bachelor programme is structured as follows: there are lectures for the whole class of a year of between 100 and 160 students, lectures for minor classes with typically 40 students, both held by senior academic staff and exercise classes, even minor in size with theoretical and practical exercises for about 25 students under the guidance of teaching assistants and student instructors. To be admitted to examinations for promotion the students have to hand in a number of individual and group assignments for approval, and examinations consist of larger project assignments, oral individual and group examinations and written examination papers at the end of a term or an academic year.

For the practical exercises the school provides the necessary technical infrastructure and IT equipment and all students are assigned an electronic mail address. Teaching material and organisational information is largely distributed through email and the programme's own electronic information, supervision and communication system, which was established 10 years ago as one of the earliest elearning systems in the country.

We base our teaching and the design of the exercises and assignments, especially in programming, programme development and databases also on the assumption that the students have increasing contact and access to computing facilities and the Internet at home or otherwise outside formal teaching and learning activities. In our choice of operating system, we expect, more or less, that the students use Windows and, beyond the classroom during the first year, also have access to programming tools associated with the programming language Java. 


\section{Research Approach}

To examine the research questions, we developed a survey instrument containing 21 questions exploring approximately 70 attributes. Most of the questions required multiple-choice type answers, and a small number of questions required simple yes-no answers. The questionnaire is provided as an appendix to this article and contained four distinct parts:

1. Part one comprised questions concerning the students' interests, motives and expectations with regard to the study programme. This part focussed on investigating individual motivation, orientation and willingness to put an effort into their education.

2. Part two explored previous knowledge of computer science disciplines to determine how many students are already familiar with the IT area. This section also examined where they had acquired skills/knowledge and attributes of the skill set and prior knowledge.

3. Part three of the instrument contained questions inquiring into participants' general educational background, especially their previous exposure to mathematics.

4. In part four we asked questions concerning the availability of computing facilities. The purpose of this was to collect data about infrastructure prerequisites.

Finally, to learn more about the students' context, although there is not necessarily a relation between external work and student disengagement, we also asked on question about paid work during studies.

As the study is of an explorative and analytical character, no hypothesises were explicitly formulated and formally tested, nor were any sophisticated statistical test runs performed. A total of 163 questionnaires were distributed to all active first year students in September 2002, four weeks after their start in the study programme and we received 159 responses; a response rate of 97,5\%. This high response rate is not surprising given that the course co-ordinator for the first year computer science education, together with the director of the whole study programme initiated and performed the investigation. The results are in the following presented as whole or rounded percentages and in relation to the total number of valid responses on the individual questions, which varied a little, but which has no significant consequence for the outcome of this type of exploration.

\section{Results}

\section{Interest, Orientation and Expectations}

An interesting starting point for studying the students' motives for choosing the Computer Science and Business Administration programme is questioning whether there is an equal interest in both subject areas, or whether there is a primary interest in one of them, and a minor interest in the other? We used a scale from 0 (no interest) to 10 (very interested) to measure the students' interest in the two subject areas. On average their interest in computer science was higher than in business administration (8.9 as compared to 7.8). The survey results indicate that most students choose the study due to their attraction to the IT field: out of 155 who gave valid answers, $66 \%$ replied "very interested" regarding computer science, while only 34\% answered the same regarding business administration. One student has answered "no interest" regarding business administration! These results are shown in Table 2. 


\begin{tabular}{|l|c|c|}
\hline \multicolumn{3}{|c|}{ Table 2: Interest in the fields of study } \\
\hline \hline \multicolumn{1}{|c|}{ Degree of Interest } & In Computer Science (in \%) & In Business Administration (in \%) \\
\hline $0-1$ (not interested) & 0 & 0,7 \\
\hline $2-3$ & 0,7 & 1,3 \\
\hline $4-6$ & 5 & 15 \\
\hline $7-8$ & 28 & 48 \\
\hline $9-10$ (very interested) & 66 & 34 \\
\hline
\end{tabular}

The data also allows for a comparison of how many students expressed a markedly higher interest (expressed in a difference equal or higher two in their individuals ratings), a higher interest (as expressed in a difference in the rating by one) or an equal interest in both subject fields. This data confirms the students' higher interest for computer science: 37\% express a markedly higher interest in computer science, even 33\% a higher interest in computer science, 15\% indicate an equal interest in the two subject areas, $10 \%$ have a higher interest in business administration and where as only $5 \%$ a markedly higher interest in business administration.

The relatively high level of interest in computer science could be a consequence of the fact that students think they know what to expect from that area given their exposure to it prior or in parallel to commencing their formal studies (see Tables $6-9$ ). Still the expressed interest ought to be a good basis for motivating the students to improve their efforts in the computer science subjects. However, from an overall perspective, it can be problematic if interest in the two subject areas is unevenly divided as the students might neglect one subject over the other. Perhaps the answers justify a little scepticism as to the credibility of the responses: the students knew that the questionnaire came from a teacher in computer science.

Such a distribution of interest might however also be a consequence of a conscious strategic decision which has to be further explored in order to inform the overall design of the programme. Thus, it would be worthy of further investigation to find out whether the students' efforts in the business administration part of the programme were similar to, or the same as the effort shown in the computer science area.

Further related to the students' orientation is the fact that most of the students (74\%) plan to complete the graduate programme, while only $7 \%$ intend to stop after the bachelor degree - the remainder (19\%) have not yet decided. This aspect should also provide an incentive for students to approach their undergraduate studies with a high level of interest and is an aspect that could be exploited by giving the students an introduction into the graduate programme early in their undergraduate programme.

\begin{tabular}{|c|c|c|}
\hline \multicolumn{3}{|c|}{ Table 3: Future plans for education } \\
\hline \hline $\begin{array}{c}\text { Stop with Bachelor } \\
\text { Degree (in \%) }\end{array}$ & $\begin{array}{c}\text { Continue for Master degree } \\
\text { (in \%) }\end{array}$ & Do not know yet (in \%) \\
\hline 7 & 74 & 19 \\
\hline
\end{tabular}

We also investigated students' perceptions of their expected future career, which might give an indication about their knowledge about which qualifications are imperative. This in turn might 
contribute to an explanation of their motives and their intended efforts. Care has however to be taken when interpreting the data as their perceptions might be influenced by the available information about the programme at the point in time when they chose it and might not mirror the qualifications which are actually required. The students' responses are presented in Table 4, where multiple answers were possible.

Most students (53\%) have no idea of what kind of work they want to carry out. As expected from students at a business university the rest of the answers are primarily divided between managing and consulting functions (in total 37\%). Only 6\% mention classical computer science oriented functions. Some indicate 'job functions' like systems developer where they may combine their computer science and business administrative knowledge.

These answers may seem to be in conflict with their interests in the two overarching subject areas of the study programme. Apparently, there is no clear connection between the students' primary subject interest and their future dream jobs where other aspects may play a part like salary, career opportunities, status, etc.. On the whole, it must be said that the positive answers fit with the programme's purpose as described in its study handbook. When interpreting the responses caution should however been taken as the students due to their earlier exposure to IT and their prior computer science expertise (see tables 6 9) might tend to imagine more IT related function as their future occupation. Before any final conclusions are made the answers concerning future occupation should therefore be carefully correlated with the data

\begin{tabular}{|l|c|}
\hline \multicolumn{2}{|c|}{ Table 4: Expected careers } \\
\hline \hline \multicolumn{1}{|c|}{ Expected career } & (in \%) \\
\hline Do not know & 53 \\
\hline Consultant & 14 \\
\hline Project manager & 8 \\
\hline Self-employed/Entrepreneur & 7 \\
\hline IT-manager & 3 \\
\hline Manager & 2 \\
\hline Programmer & 2 \\
\hline Project worker & 2 \\
\hline Systems developer & 1 \\
\hline Financial manager & 8 \\
\hline Administrator & 1 \\
\hline Others (all different) & \\
\hline \hline
\end{tabular}
concerning their upper secondary education, especially for those who have finished a commercial upper secondary school (see Table 10).

Yet, it can be concluded that due to a lack of a clear idea of the expected future career, there is a risk that the students do not know which qualifications may be important. The study programme should perhaps clarify this early on, and provide the first year students with an introduction to the various relevant job types.

In this context it is interesting that only very few students (3\%) are in doubt about which qualifications within the IT area they expect to achieve through the study. Table 5 contains the results concerning this question where multiple answers were possible.

The large majority (from 65\% to 86\%) expect to acquire qualifications to perform management functions (project manager/computer manager). It is interesting that between 30\% and 55\% expect to be qualified to perform solely IT-oriented work functions (depending on the type of function concerned). If these answers are compared to the responses concerning the students' 'dream' job expectations, this might be a sign of that many students regard the knowledge they acquire in the computer science subject field as background knowledge, which they do not expect to use actively in their working life. This is in line with the actual career of many graduates of the programme who become specialists in organisational change processes enabled or related to IT, but 
who rarely are involved in the actual technical development or implementation of the underlying soft- and hardware.

It should also be mentioned that only $4 \%$ expect to be qualified to perform consultant functions within the IT area, while $14 \%$ answered that their 'dream' job was a consultant job. This may imply two things: either that their 'dream' job as a consultant is not within the IT area or that they expect the consulting functions beyond the classes in computer science and business administration with its emphasis on organisations, economy and IT management will require further qualifications.

\section{Previous Knowledge of Computer Science Disciplines}

In total 120 students (76\%) answer that they have previous knowledge of the field of study. First and foremost they have prior expertise in programming, database technology and web design. However between $22 \%$ and $56 \%$ have no previous knowledge

\begin{tabular}{|l|c|}
\hline \multicolumn{2}{|c|}{$\begin{array}{c}\text { Table 5: Perceived job qualification } \\
\text { obtained through the study programme }\end{array}$} \\
\hline \hline Qualifications for a job as & (in \%) \\
\hline Project manager & 86 \\
\hline Computer manager & 65 \\
\hline Systems developer & 55 \\
\hline Database administrator & 50 \\
\hline Programmer & 30 \\
\hline Web-designer & 19 \\
\hline Consultant & 4 \\
\hline Don't know & 3 \\
\hline
\end{tabular}
of any of the computer science disciplines. Table 6 shows the results.

\begin{tabular}{|l|c|c|c|c|}
\hline \multicolumn{4}{|c|}{ Table 6: Extent of prior knowledge of computer science disciplines } \\
\hline Discipline & None (in \%) & Little (in \%) & Some (in \%) & A lot (in \%) \\
\hline Programming & 22 & 39 & 32 & 8 \\
\hline $\begin{array}{l}\text { Database technol- } \\
\text { ogy }\end{array}$ & 28 & 46 & 24 & 3 \\
\hline Web design & 23 & 31 & 25 & 18 \\
\hline $\begin{array}{l}\text { Systems develop- } \\
\text { ment }\end{array}$ & 56 & 27 & 16 & 2 \\
\hline Operation systems & 40 & 33 & 15 & 12 \\
\hline Other & 2 & 7 & 7 & - \\
\hline \hline
\end{tabular}

Concerning the distribution of programming languages 91 students acknowledge previous knowledge with Visual Basic (40\%) as the top scorer, and Java as the runner up (35\%), and C++ (24\%) and Pascal (23\%) on the following places. In addition, $48 \%$ of the students answered that they are acquainted with SQL.

Most of the respondents have acquired their knowledge from self-directed learning. Other relevant sources to their previous knowledge are upper secondary education, other schools and educations, including work. Table 7 includes the answers to the respective question. 
When so many students have previous knowledge as indicated in the survey this should be considered in the programme's curriculum design. However, further investigation of this issue is needed, which should encompass indepth studies of the skill level of freshman students and which should interrogate their expertise in more specific themes within the various computer science disciplines.

Concerning work in the IT area shown in Table 8 - where multiple answers were possible 61 students answer that they work or have worked in the field and depending on the definition of the job title $66 \%$ - $82 \%$ of them have or have had work functions that are directly related to computer science subjects in the programme (programmer, systems developer, web designer). This corresponds with the answers to the earlier question where $40 \%$ mention their work as one of the sources to their previous knowledge.

Table 9 shows which other educations the students have been starting and/or completed before commencing the Computer Science and Business Administration programme. In total 50 students have been involved in one or another - multiple answers were possible - education. In most cases, this was some type of IT education such as computer technician, computer scientist, multimedia designer, etc. Approximately $25 \%$ have completed the education in question. Thus, a large group of students has also acquired knowledge within the IT area from a previously completed or partly completed higher education.

We can therefore conclude that there is a large variation of prior knowledge among the students, which presents a challenge for the design of an educational programme.

Table 7: Sources of previous knowledge of computer science disciplines

\begin{tabular}{|l|c|}
\hline Source & in \% \\
\hline Self study & 61 \\
\hline Upper secondary school & 42 \\
\hline Job & 40 \\
\hline Other education & 27 \\
\hline Primary and lower secondary school & 10 \\
\hline \hline Other & 7 \\
\hline
\end{tabular}

Table 8: Students' job functions within the IT area

\begin{tabular}{|l|c|}
\hline Job title & in \% \\
\hline Operator/ Operations employee & 33 \\
\hline Web designer & 33 \\
\hline Programmer & 20 \\
\hline Salesperson & 15 \\
\hline Systems developer & 10 \\
\hline Support & 7 \\
\hline Consultant & 5 \\
\hline Page boy & 23 \\
\hline Other & 13 \\
\hline \hline
\end{tabular}




\begin{tabular}{|c|c|c|}
\hline \multicolumn{3}{|c|}{$\begin{array}{r}\text { Table 9: Other educations before } \\
\text { the start of the programme }\end{array}$} \\
\hline Education & $\begin{array}{l}\text { Not completed } \\
\text { (in \%) }\end{array}$ & $\begin{array}{l}\text { Completed } \\
\text { (in \%) }\end{array}$ \\
\hline Computer Technician & 20 & - \\
\hline Master of Economics & 11 & 2 \\
\hline Computer Science & 9 & - \\
\hline Multimedia Design & 2 & 4 \\
\hline $\begin{array}{l}\text { BSc in Economics and Busi- } \\
\text { ness Adm. }\end{array}$ & 7 & - \\
\hline Media Coordinator & - & 4 \\
\hline Graduate Engineer & 4 & - \\
\hline IT and English & 4 & - \\
\hline IT-Diploma Engineer & 4 & - \\
\hline Academy of Communication & - & 2 \\
\hline School Teacher & - & 2 \\
\hline Office Assistant & - & 2 \\
\hline $\begin{array}{l}\text { BSc. in Int. Business Adm. } \\
\text { and Modern Languages }\end{array}$ & - & 2 \\
\hline Other & 22 & 7 \\
\hline
\end{tabular}

\section{General Secondary Education}

Mathematics on a Danish A or B level is one of the formal requirements for admission to the programme and as shown in Table 10 more than half (58\%) of the students have specialised in this education area.

However the responses presented in Table 11 - where again multiple answers were possible- indicate that not all students have had mathematics at the required higher A or B level, but only $84 \%$ of them.

\begin{tabular}{|l|c|}
\hline \multicolumn{2}{|c|}{$\begin{array}{c}\text { Table 10: General and vocational upper } \\
\text { secondary education }\end{array}$} \\
\hline Education type & in \% \\
\hline Mathematics & 58 \\
\hline $\begin{array}{l}\text { Commercial upper secondary } \\
\text { school }\end{array}$ & 30 \\
\hline Higher preparatory examination & 13 \\
\hline Languages & 12 \\
\hline Other & 11 \\
\hline \hline
\end{tabular}

Table 11: Subjects taken on top level (A or B level)

\begin{tabular}{|l|c|}
\hline Job title & in \% \\
\hline Mathematics & 84 \\
\hline English & 70 \\
\hline Danish & 63 \\
\hline Physics & 37 \\
\hline Other & 59 \\
\hline
\end{tabular}

A check with the study secretariat showed that no exemptions from the requirement were granted. Only a few students were admitted to the programme on the condition that they qualify on the B 
level before the programme starts. This is possible through special summer courses and this qualification was achieved. Otherwise, they would not have been admitted.

Therefore, one explanation for the result could be a possible misunderstanding of the question we asked for subjects taken on 'top level'. The most obvious reason is that some students have omitted to check off the answer as they did not have mathematics at an A level and as a student of the programme, at least B level is necessary, which to the students themselves is not a high level. Thus, the question was misleading in its formulation and even absurd when the requirement for the programme is mathematics at the B level. In fact, the question and the answers reflect the confusion that prevails in Denmark - even in the upper secondary school - concerning the level concept, the individual marks and obligatory and elective classes.

In a follow-up survey, it would be worthwhile to examine how the B and A levels in mathematics are distributed, as in practise in teaching in our school, it is difficult to believe that all students have mathematics on at least the B level. The teachers report that students often react negatively towards anything that has to do with mathematics - even more elementary mathematics. This means that there is a limit to how thoroughly these topics can be reviewed in class, regardless of whether they are directly relevant for a concrete task or not. It would be interesting to learn more about the students' attitude towards mathematics in relation to the study programme and how this problem is solved in the other, business related subjects where mathematics also plays a part.

\section{Computing Facilities at Home and at Work}

As we described earlier our teaching in computer science is based on the assumptions, that the students have a computer and access to the Internet at home and that they use the programme's IT based study support system, not just at the school, but as a natural part of their studies at home.

Our research shows that that these assumptions are correct: 97,5\% of the first year students in 2002 have a computer, 93\% with Windows and 80\% with Internet access at home. The majority of the students (54\%) are employed. Out of the 85 students, who work, only $67 \%$ have Internet access at work - probably because the remaining 28 students have a job that is not IT-oriented, which corresponds to the responses to the respective earlier question. Out of the 16 who do not have Internet access at home, 5 have access at work. In total, 93\% students have Internet access outside the school. In other words these facilities may almost be regarded on a par with paper and pencils as being a part of the students' equipment.

Regarding the operating system used at work, the situation corresponds to the students' access to a computer at home: Windows dominates - but as we might expect, industry lags behind when it comes to version. In sum, these results confirm the above conclusions regarding IT as a natural toolset for the students and might in the future be used more intentionally and explicitly for the set up and operation of the education.

\section{External Work Load and Study Effort}

As stated 54\% of the students have a job. By itself, this result cannot answer why so few students participate in the class activities and prepare for lessons - according to the teachers of the programme, it is less than half of the students who take an active part in the exercises. Other reasons related to the young undergraduates general, life circumstances, e. g. their adjustment to student life in a metropolitan city as well as the overall requirements and work load of the study programme have to be explored and reviewed.

Beyond these issues, this result, also suggests a couple of other obvious questions in a follow-up survey: how much time do the students spend on the different study activities - lectures, theorybased and practical exercises, assignments - and how many hours do they spend on the job a 
week? Answers to these questions should definitely have a consequence on the design of the course programme and the advice given to prospective and freshman students.

\section{Conclusion and Future Research}

The outcome of our survey provides first results concerning freshman students' orientation, their prior knowledge and their wider background, which might influence the current and future teaching and learning of computer science topics in higher education.

While further research of this kind is needed, both in a more rigorous way and with different samples, our findings provide a number of relevant first indications. In our case where computer science is taught in a multidisciplinary programme, results suggest that there ought to be a good basis for motivating our students to improve their efforts in the computer science subjects. However, as the majority of students do not know what kind of work they want to carry out in the future, information to first year students about the MSc programme and relevant jobs should be provided. The survey also shows that IT is a natural toolset for the students, which in the future should be used more deliberately for the education.

The findings regarding the students' previous knowledge lead to the survey's main conclusion: the students' previous knowledge seems to be so comprehensive that it cannot be ignored, but should be considered in the teaching in the first year of the study programme, and perhaps should inform the curriculum design for all year levels. On the other hand, there are still a substantial number of students who arrive at the programme with no previous knowledge. They may easily be left behind their more advanced peers and eventually become despondent and get the wrong impression of what is expected of them. It is therefore necessary to design a syllabus and organise the course to accommodate different types of students. For this reason it would presumably be an advantage and a good starting point for the individual student if he or she was given tools to evaluate his or her previous knowledge in relation to the syllabus.

Concerning the students' disengagement and its possible relation to their external workload, no conclusions can be drawn and this issue has to be thoroughly researched in a follow-up survey. The same is true about the students' expertise in mathematics.

It is therefore our plan to improve the survey instrument along the lines outlined throughout this paper and repeat the data collection with the new freshman students of the coming academic years. These successive surveys will include items:

- to investigate the students' wider context of study, e.g. their gender, age, backgound, social relationships, reasons of external work, number of hours spent on job, but also the distribution of mathematics on level $\mathrm{A}$ and $\mathrm{B}$, and the time consumption on the the different study activities

- to map out the students previous knowledge in more detail in relation to depth and themes within the computer science and business administration disciplines

- to explore whether and how the mathematics problem is solved in the other subject areas, e.g. business administration.

In general, to get a richer picture of the study programme as a whole with regard to knowledge disparity and student disengagement we intend to adjust the survey instrument to perform similar investigations among the second and third year students and compare these with the responses given by the first year students. This should provide insights for informed changes of our educational scheme. 


\section{Acknowledgement}

The authors like to thank the four anonymous reviewers of the article for their most valuable comments and improvement proposals. Thanks are also due to the first year students of the Computer Science and Business Administration programme who participated in the survey.

\section{References}

Beaubouef, T. (2002). Why computer science students need math. SIGCSE Bulletin, ACM Press, 34 (4), 57-59.

Denning, P. (1992). Educating a new engineer. Communications of the ACM, 35 (12), 83-97.

Denning, P., Comer, D.E., Gries, D., Mulder, M. C., Tucker, A., Turner, A. J., \& Young, P. R. (1989). Computing as a discipline. Communications of the ACM, 32 (1), 9-23.

Dijkstra, E. W. (1989). On the cruelty of really teaching computing science. Communications of the ACM, 32 (12), 1398-1404.

Gries, D. (1991). Calculation and discrimination: A more effective curriculum. Communications of the ACM, 34 (3), 45-55.

Flyvberg, B. (1992). Rationality and Power - The Science of the Concrete. In Danish. Academic Publisher, Copenhagen, Denmark.

Kautz, K. (1996). User participation and participatory design - Topics in computing education. Journal of Human Computer Interaction, 11 (3), 267-284.

McInnis, C., James, R., \& Hartley, R. (2000). Trends in the first year experience: In Australian universities. Austrailan Government - Department of Education, Science and Training publications, DETYA, Canberra, Australia.

McInnis, C., James, R., \& McNaught, C. (1995). First year on campus: Diversity in the initial experiences of Australian undergraduates. Australian Government - Department of Education, Science and Training publications, DETYA, Canberra, Australia.

Meredyth, D., Russel, N., Blackwood, K., Thomas, J., \& Wise, P. (1999). Real time: Computers, change and schooling. Australian Government - Department of Education, Science and Training publications, DETYA, Canberra, Australia.

Samaka, M. (2002). Changing a computer science curriculum in light of the Computing Curriculum 2001. SIGCSE Bulletin, ACM Press, 34 (4), 32-35.

\section{Appendix: The Results of the Survey}

The form below shows the results of the survey. For every question, we find the number of legal responses in the column Total and the number and response rate in the column Response, respectively. In every case, the percentage is calculated in relation to the figure in the column Total. If it is possible to mark more than one of the possible answers, it is indicated in the column Text "(more answers)". With regard to some questions, it is possible to add other answers than the ready printed answers. These are collected in main groups and marked with an * in the column Response. In questions with several response options, these are sorted according to declining number of responses in the column Total.

\begin{tabular}{|l|l|l|l|}
\hline $\begin{array}{l}\text { Qu. } \\
\text { nr. }\end{array}$ & Text & Response & Total \\
\hline 1 & Do you have a PC at home? & $\begin{array}{l}\text { Yes: } 155 / 97 \% \\
\text { No: } 4 / 3 \%\end{array}$ & 159 \\
\hline 2 & Do you have Internet access at home? & Yes: $137 / 90 \%$ & 153 \\
\hline
\end{tabular}


Studying Computer Science in a Multidisciplinary Degree Programme

\begin{tabular}{|c|c|c|c|}
\hline & & No: $16 / 10 \%$ & \\
\hline 3 & $\begin{array}{l}\text { Which operation system does your PC } \\
\text { use? } \\
\text { Windows XP: } \\
\text { Windows 98: } \\
\text { Windows 2000: } \\
\text { Windows ME: } \\
\text { Windows (unspec.): } \\
\text { Windows 95: } \\
\text { Windows NT: } \\
\text { Mac OS: } \\
\text { Don't know: } 3 \text { / 2\% }\end{array}$ & $\begin{array}{l}93 / 61 \% * \\
25 / 16 \% * \\
22 / 14 \% * \\
4 / 3 \% * \\
3 / 2 \% * \\
1 / 1 \% * \\
1 / 1 \% * \\
1 / 1 \% * \\
3 / 2 \%\end{array}$ & 153 \\
\hline 4 & $\begin{array}{l}\text { Do you have paid work during your } \\
\text { studies? }\end{array}$ & $\begin{array}{l}\text { Yes: } 85 \text { / 54\% } \\
\text { No: } 72 \text { / } 46 \%\end{array}$ & 157 \\
\hline 5 & Do you have Internet access at work? & $\begin{array}{l}\text { Yes: } 57 \text { / } 70 \% \\
\text { No: } 25 \text { / 30\% }\end{array}$ & 82 \\
\hline 6 & $\begin{array}{l}\text { Which operation system is used at your } \\
\text { work? } \\
\text { Windows 2000: } \\
\text { Windows NT: } \\
\text { Windows XP: } \\
\text { Windows 98: } \\
\text { Windows 95: } \\
\text { Windows (unspec.): } \\
\text { Windows ME: } \\
\text { Mac OS: } 1 \text { * } \\
\text { Don't know: }\end{array}$ & $\begin{array}{l}22 / 33 \% * \\
12 / 18 \% * \\
9 / 14 \% * \\
5 / 8 \% * \\
4 / 6 \% * \\
4 \text { / } 6 \% * \\
3 / 5 \% * \\
1 / 2 \% * \\
6 / 9 \%\end{array}$ & 66 \\
\hline 7 & $\begin{array}{l}\text { Which general and vocational upper } \\
\text { secondary education do you have? } \\
\text { Mathematics: } \\
\text { Languages: } \\
\text { Higher preparatory examination: } \\
\text { Commercial upper secondary school: } \\
\text { Other: }\end{array}$ & $\begin{array}{l}93 / 58 \% \\
12 \text { / } 8 \% \\
13 / 8 \% \\
30 / 19 \% \\
11 / 7 \%\end{array}$ & 159 \\
\hline 8 & $\begin{array}{l}\text { Which subjects did you take on top } \\
\text { level (A or B level) at your upper sec- } \\
\text { ondary education? } \\
\text { (More answers) } \\
\text { Mathematics: }\end{array}$ & & 158 \\
\hline
\end{tabular}




\begin{tabular}{|c|c|c|c|c|}
\hline & $\begin{array}{l}\text { English: } \\
\text { Physics: } \\
\text { Danish: } \\
\text { Other: }\end{array}$ & \multicolumn{2}{|l|}{$\begin{array}{l}132 / 84 \% \\
111 / 70 \% \\
59 / 37 \% \\
99 \text { / } 63 \% \\
94 / 59 \%\end{array}$} & \\
\hline 9 & $\begin{array}{l}\text { After graduating from your upper sec- } \\
\text { ondary education, did you start on an- } \\
\text { other education before you started on } \\
\text { the Business Administration and Com- } \\
\text { puter Science Degree Programme? }\end{array}$ & \multicolumn{2}{|l|}{$\begin{array}{l}\text { Yes: } 50 \text { / 33\% } \\
\text { No: } 102 \text { / 67\% }\end{array}$} & 152 \\
\hline 10 & $\begin{array}{l}\text { If yes, which educations? } \\
\text { (More answers) } \\
\text { Computer specialist: } \\
\text { Master of Economics: } \\
\text { Computer Science: } \\
\text { Multi-media designer: } \\
\text { BSc in Economics and Business Adm.: } \\
\text { Media coordinator: } \\
\text { Graduate Engineer: } \\
\text { IT and English: } \\
\text { IT-Diploma Engineer: } \\
\text { Academy of Communication: } \\
\text { School teacher: } \\
\text { Office assistant: } \\
\text { BSc. in International Business Adm. } \\
\text { and Modern Languages: } \\
\text { Other: }\end{array}$ & \multicolumn{2}{|c|}{ 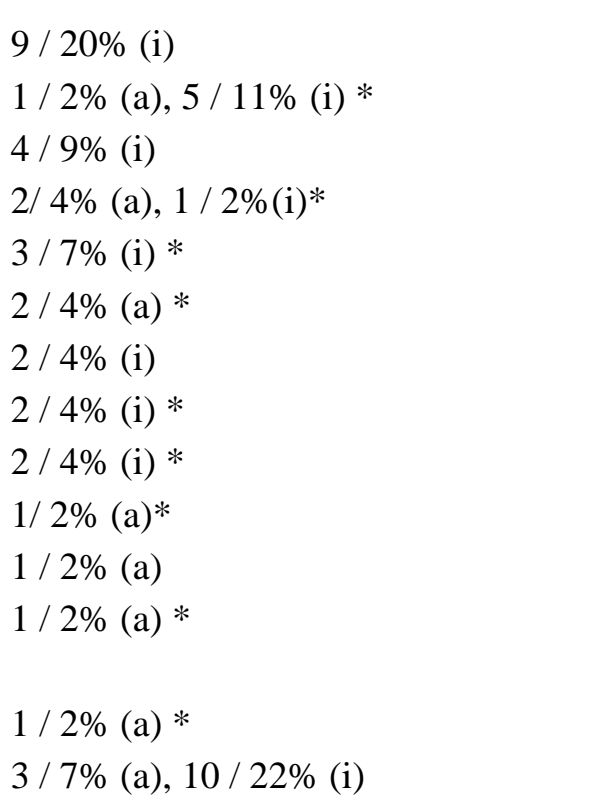 } & 45 \\
\hline 11 & $\begin{array}{l}\text { On a scale from } 0-10 \text {, indicate your } \\
\text { interest for the two subject areas at the } \\
\text { Business Adm. and Computer Science } \\
\text { Degree Programme. } \\
(0=\text { no interest, } 10=\text { very interested) }\end{array}$ & $\begin{array}{lll}0-1 & 0 & 1 \\
2-3 & & 1 \\
4-6 & & 8 \\
7-8 & & 44 \\
9-10 & & 102 \\
& & \\
& & \\
\text { Average } & 8.9\end{array}$ & $\begin{array}{lll} & \text { C.S. B.A. } \\
2 & & \\
24 & & \\
75 & & \\
53 & & \\
7.8 & & \end{array}$ & 155 \\
\hline 12 & $\begin{array}{l}\text { After completing your bachelor degree } \\
\text { in Business Adm. and Computer Sci- } \\
\text { ence do you anticipate to stop or do you } \\
\text { want to continue with a MSc. Degree in } \\
\text { the same subject? } \\
\text { BSc: } \\
\text { MSc.: }\end{array}$ & 11 / 7\% & & 158 \\
\hline
\end{tabular}




\begin{tabular}{|c|c|c|c|}
\hline & Don't know: & $\begin{array}{c}117 / 74 \% \\
30 / 19 \%\end{array}$ & \\
\hline 13 & $\begin{array}{l}\text { What is your dream job when you have } \\
\text { completed you education (not later in } \\
\text { your career but immediately after your } \\
\text { graduation)? } \\
\text { (More answers) } \\
\text { Consultant: } \\
\text { Project manager: } \\
\text { Self-employed: } \\
\text { IT-manager: } \\
\text { Manager: } \\
\text { Programmer: } \\
\text { Project work: } \\
\text { Systems developer: } \\
\text { Financial manager: } \\
\text { Administrator: } \\
\text { Other: (all different) } \\
\text { Don't know: }\end{array}$ & $\begin{array}{l}20 / 14 \% * \\
17 / 11 \% * \\
12 / 8 \% * \\
10 / 7 \% * \\
5 / 3 \% * \\
3 / 2 \% * \\
3 / 2 \% * \\
3 / 2 \% * \\
2 / 1 \% * \\
2 / 1 \% * \\
12 / 8 \% \\
80 / 53 \%\end{array}$ & 152 \\
\hline 14 & $\begin{array}{l}\text { To which functions within IT do you } \\
\text { expect that a degree in Business Ad- } \\
\text { ministration and Computer Science will } \\
\text { qualify you (regardless of whether you } \\
\text { wish to perform these functions)? } \\
\text { (More answers) } \\
\text { Project manager: } \\
\text { Computer manager: } \\
\text { Systems developer: } \\
\text { Database administrator: } \\
\text { Programmer: } \\
\text { Web-designer: } \\
\text { Consultant: } \\
\text { Don’t know: }\end{array}$ & $\begin{array}{l}136 \text { / 86\% } \\
104 \text { / 65\% } \\
87 \text { / 55\% } \\
79 \text { /50\% } \\
47 \text { / 30\% } \\
30 \text { / 19\% } \\
6 \text { / 4\%* } \\
5 \text { / 3\% }\end{array}$ & 159 \\
\hline 15 & $\begin{array}{l}\text { Are you already acquainted (even if it is } \\
\text { only slightly) with one or more com- } \\
\text { puter science disciplines (e.g. pro- } \\
\text { gramming, database technique, web- } \\
\text { design, systems development, operation } \\
\text { systems technique, etc.)? }\end{array}$ & $\begin{array}{l}\text { Yes: } 120 \text { / 76\% } \\
\text { No: } 38 \text { / 24\% }\end{array}$ & 158 \\
\hline
\end{tabular}




\begin{tabular}{|c|c|c|c|c|}
\hline 16 & $\begin{array}{l}\text { Where have you acquired such knowl- } \\
\text { edge? (More answers) } \\
\text { Self-study: } \\
\text { Upper secondary school: } \\
\text { Job: } \\
\text { Other education: } \\
\text { Primary and lower secondary school: } \\
\text { Other: }\end{array}$ & $\begin{array}{c}69 \text { / } 61 \% \\
47 \text { / 42\% } \\
45 \text { / 40\% } \\
30 \text { / 27\% } \\
11 \text { / 10\% } \\
8 \text { / 7\% }\end{array}$ & & 113 \\
\hline 17 & $\begin{array}{l}\text { Describe your knowledge in relation to } \\
\text { the different computer science disci- } \\
\text { plines. } \\
\text { Programming } \\
\text { Database technology } \\
\text { Web-design } \\
\text { Systems development } \\
\text { Operation systems } \\
\text { Other: }\end{array}$ & $\begin{array}{ll}\text { none } & \text { little } \\
& \\
& \\
& \\
26 / 22 \% & 47 / 39 \% \\
33 / 28 \% & 55 / 46 \% \\
28 / 23 \% & 37 / 31 \% \\
67 / 56 \% & 32 / 27 \% \\
48 / 40 \% & 40 / 33 \% \\
& 2\end{array}$ & 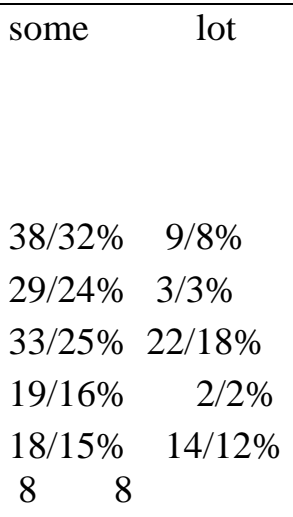 & 120 \\
\hline 18 & $\begin{array}{l}\text { Which programming language are you } \\
\text { acquainted with? } \\
\text { (More answers) } \\
\text { Visual Basic: } \\
\text { Java: } \\
\text { C++: } \\
\text { Pascal: } \\
\text { PHP: } \\
\text { ASP: } 9 \\
\text { HTML: } 8 \\
\text { Delphi: } 5 \\
\text { MySQL: } 2 \text { / } 2 \\
\text { Other: }\end{array}$ & $\begin{array}{l}36 \text { / } 40 \% \\
32 \text { / } 35 \% \\
22 \text { / } 24 \% \\
21 / 23 \% \\
9 \text { / 10\%* } \\
9 \text { / } 10 \% * \\
8 \text { / } 9 \% * \\
5 \text { / } 5 \% * \\
2 \text { / } 2 \% * \\
11 / 12 \%\end{array}$ & & 91 \\
\hline 19 & Are you acquainted with SQL? & $\begin{array}{l}\text { Yes: } 44 \text { / 37\% } \\
\text { No: } 74 \text { / 63\% }\end{array}$ & & 118 \\
\hline 20 & $\begin{array}{l}\text { Do you or have you worked within the } \\
\text { IT area? }\end{array}$ & $\begin{array}{l}\text { Yes: } 61 \text { / 50\% } \\
\text { No: } 62 \text { / 50\% }\end{array}$ & & 123 \\
\hline 21 & $\begin{array}{l}\text { What was/is your function? } \\
\text { Operator/ operations employee: } \\
\text { Web-designer: }\end{array}$ & $\begin{array}{l}20 / 33 \% \\
20 / 33 \%\end{array}$ & & 61 \\
\hline
\end{tabular}




\begin{tabular}{|l|l|l|}
\hline Page boy: & $14 / 23 \% *$ & \\
Programmer: & $12 / 20 \%$ & \\
Salesperson: & $9 / 15 \%$ & \\
Systems developer: & $6 / 10 \%$ & \\
Support: & $4 / 7 \% *$ & \\
Consultant: & $3 / 5 \% *$ & \\
Other: & $8 / 13 \%$ & \\
\hline
\end{tabular}

\section{Biographies}

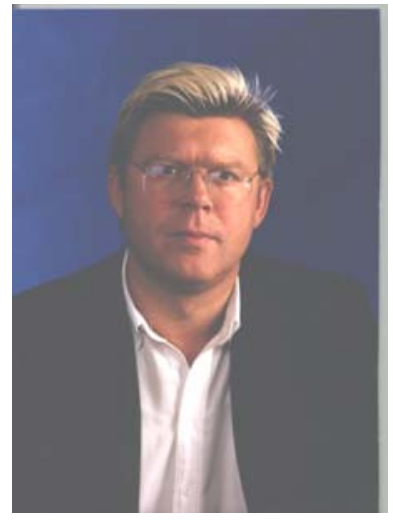

Karlheinz Kautz is professor in systems development and software engineering at the Department for Informatics and currently Director of Studies for the combined BSc and MSc degree programme in Computer Science and Business Administration at Copenhagen Business School. He holds a PhD in systems development and MSc in software development. He is the chair of the IFIP TC 8 WG 8.6 on the adoption and diffusion of IT.

His work has been published internationally on conferences and in journals including Information Systems Journal, Informing Science Journal, Information Technology and People, IEEE Software, Information and Software Technology, Scandinavian Journal of Information Systems, and Journal of Knowledge Management.

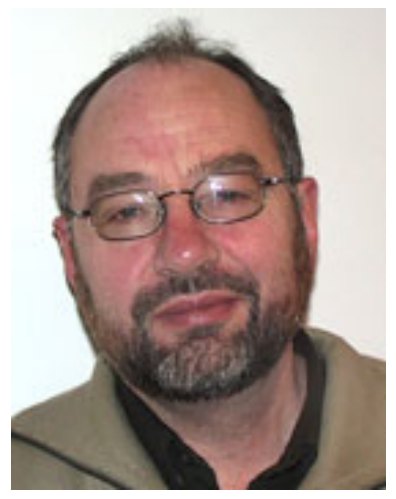

Uffe Kofoed is lecturer at the Department for Informatics at the Copenhagen Business School and currently he is the co-ordinator of the programming education of the bachelor programme and responsible for the open study programme to qualify data technicians for the bachelor degree in the combined BSc and MSc degree programme in Computer Science and Business Administration. His research interests are in programming and in programming and document mark up languages with a special emphasis on object-oriented approaches and programming pedagogy. 